\title{
13 Archives for memory and justice in Colombia after the Peace Agreements
}

\author{
Ramon Alberch i Fugueras
}

\section{The historical and political contexts}

Putting an armed conflict like the Colombian case into context in a few lines is a complicated task - a conflict that has endured more than 50 years under a democratic state and which has taken on multiple forms of victimisation by a number of different protagonists (guerrilla, paramilitary and self-defence groups, the armed forces, etc.). This multiplicity of players with conflicting interests has led some stakeholders to deny the existence of an armed conflict which is clearly a response to structural causes and manifest inequality. As Gonzalo Sánchez points out: many people would like to continue seeing the current violence as simply an expression of crime or banditry, and not as a manifestation of fundamental problems in the make-up of our political and social order (Centro Nacional de Memoria Histórica, 2013, p. 13). ${ }^{1}$

The causes of the conflict are many and complex; the most relevant ones being that the appropriation, use and possession of land have been the driving force behind the origin and persistence of the armed conflict, added to which are other problems: drug trafficking, mining and energy supply, agro-industrial models and criminal alliances between paramilitary groups, politicians, public servants, local business and financial elites, and drug traffickers (Centro Nacional de Memoria Histórica, 2013, p. 21). This violence has undergone notable transformations, both in its forms of victimisation and its geographical location.

Furthermore, a certain democratic precariousness has been evident in the prioritisation of repressive and military options for tackling a situation of conflict due to corruption, impunity, racism, poverty, and exclusion. The political pact between liberals and conservatives to preserve a two-party model - the "National Front" (1958-1974), and the unconditional adherence to the so-called National Security Doctrine which reflected a notorious fear of communism and assumptions of a phantasmagorical "internal enemy", has prevented a consensus-based solution to the internal armed conflict. At the same time, the few peace initiatives undertaken in the 1980s and 1990s failed to succeed in taking root or facilitating any de-escalation of the conflict. 


\section{Ramon Alberch i Fugueras}

The study "Basta ya!" (Enough Is Enough!) produced by the Group for the Historical Memory (Grupo de Memoria Histórica) proposes a division of the conflict into phases reflecting the fact that the lethal nature of the violence has been neither homogeneous nor constant. In the following, we summarise these phases:

1958-1964: a decreasing trend. Transition from bipartisan to subversive violence

1965-1981: low level violence, fairly stable in its degree. Guerrilla incursions and their confrontation with the state ${ }^{2}$

1982-1995: growth in violence marked by the expansion of guerrilla groups, the incursions of paramilitary groups, the spread of drug trafficking and the crisis of state

1996-2002: an explosive trend. Military strengthening of the guerrillas, expansion of the paramilitary groups, reconfiguration of drug trafficking, and the economic crisis and crisis of state

2003-present (2016): a decreasing trend. Military initiative taken by the state, withdrawal of guerrilla groups and partial demobilisation of the paramilitary groups (Centro Nacional de Memoria Histórica, 2013, p. 33)

On a general level, as violence is principally based in the rural environment, occurring daily and focused on anonymous individuals, a certain proportion of the population in the big cities has not felt affected or involved (through a sad mixture of passivity and indifference), living in a situation of apparent peace and prosperity, with a comfortable perception of political and economic stability. The impact of this frequent, low-intensity violence, which does not reach the national level but has a high impact at the local level, reveals a level of numbers which is truly terrifying.

Between 1958 and 2012, the armed conflict caused the death of at least 220,000 people, a figure that is currently being revised upwards by the Single Registry of Victims (RUV: Registro Único de Víctimas) implemented by Act 1448/2011 on victims and land restitution. To this figure should be added those killed in war (40,787 combatants between 1958 and 2012), as well as "non-lethal" violence with serious consequences: 25,007 missing persons, 1,754 victims of sexual violence, 6,421 children and adolescents recruited by armed groups, 27,023 kidnapped between 1970 and 2010, 10,440 victims for landmines between 1982 and 2012 (Centro Nacional de Memoria Histórica - Fundación Prolongar, 2017), ${ }^{3}$ and 4,744,046 internally displaced persons (which could be increased to around 5.6 million if we add the 819,510 displaced persons between 1985 and 1995, according to data provided by CODHES, the Consultancy for Human Rights and Displacement, i.e. almost $15 \%$ of the total Colombian population; or almost 7 million in recent figures provided by the Unit for Comprehensive Care and Reparation of Victims, 2019). 
And this violence, according to the National Observatory for the Memory and Armed Conflict (ONMC: Observatorio Nacional de Memoria y Conflicto armado), has taken ten different forms: warlike action, attacks on populations, selective assassinations, massacres, terrorist attacks, sexual violence, kidnappings, forced disappearance, recruitment of minors and adolescents, and damage to private property. The 1991 Political Constitution enshrines peace as a right and allows for the opening of avenues to broaden political involvement. Finally, with the signing of the Final Agreement to end the conflict and build a stable and lasting peace, on 24 November 2016, between the national government and the FARC-EP guerrillas, there are now great expectations of a definitive end to the armed conflict, although not without difficulties in the face of the negative reactions of some groups involved in the violence (notably the National Liberation Army (ELN) and a small group of former members of the FARC).

\section{The legal framework}

The political will to put an end to the armed conflict has produced a plethora of regulations which have highlighted the relevance of the institutions in charge of engineering the process of transitional justice, ${ }^{4}$ and which fully comprehend the importance of the organization and custody of, and access to, public and private archives as indispensable tools to achieve justice, reparation, the guarantee of non-repetition, and which uphold the principle of truth.

For the sake of clarity, we shall limit ourselves to listing the most relevant laws and, especially, those that create transitional bodies of justice that have the task of drafting, processing, and utilising a great variety of documents intensively in order to achieve their goals. It should be noted that with the acceptance of the concept of transitional justice, it is assumed that the criterion should prevail that war crimes and crimes against humanity cannot go unpunished, and the aim is to satisfy the minimum requirements laid down by courts and international bodies, in addition to reiterating the need to give the victims of the conflict clear satisfaction in three aspects: knowledge of what happened - for the fulfilment of their purposes (the truth); that there is a minimum acceptable punishment (justice); and that there are forms of compensation for the victims, whether moral or material (reparations) (Meto, 2016, pp. 319-337). ${ }^{5}$

The regulations drawn up in Colombia in recent years are abundant and complex. ${ }^{6}$ Thus, the National Archives (AGN, Archivo General de la Nación), in addition to Act 594/2000 on archives, on which the Colombian archival system is based, has also produced various circulars and agreements referring to the identification, location, organization and protection of archives relating to the armed conflict. ${ }^{7}$ With regard to State legislation, worthy of note is Law 975/2005 on Justice and Peace; Law 1424/2010 which lays down transitional justice provisions to guarantee truth, justice, 
and reparations for the victims of demobilised members of organised groups outside the law and grant legal benefits; as well as Law 1448/2011 on victims and land restitution which provides a new approach to tackling the conflict based on the trilogy of Land, Truth, and Reparations.

This last law, regulated in Decree 4800/2001, in Article 189 orders the creation of a Special Registry of Archives of the Human Rights and Historical Memory Program in coordination with National Centre for Historical Memory (CNMH, Centro Nacional de Memoria Histórica) and the AGN, as well as orders both entities that prepare an archival policy protocol in DH and IHL and, finally, Article 191 prescribes that the AGN must create an internal working group, called "Group of Ethnic Archives and Human Rights". ${ }^{8}$

The creation of the CNMH resulted from the aforementioned Law 1448/2011, and has been further developed by decrees. ${ }^{9}$ The Legal Branch has also produced specific agreements for archive management with regard to drafting policies, setting up archive committees and laying down principles aimed at regulating document management. ${ }^{10}$ Finally, with the signing of the Peace Agreement, ${ }^{11}$ the Comprehensive System of Truth, Justice, Reparations and Non-Repetition or SIVJRNR (Sistema Integral de Verdad, Justicia, Reparación y No Repetición) was created, which develops a group of bodies in which the use of documents and archives acquire a central role. We refer especially to the Commission for the Clarification of the Truth: the CEV; the Special Unit for the Search of Missing Persons, the UBPD; and the Special Jurisdiction for Peace, the JEP.

It should be noted that the abundance of laws and, especially, the creation of numerous bodies involved in the resolution of the armed conflict has given rise to a number of dissenting voices, such as that of Winifred Tate (2007), who denounces "a fragmented, overlapping and confusing bureaucratic proliferation of state bodies with some incidence and responsibility for human rights, a real maze that forces one to go through several offices without result".

\section{The central nature of the archives}

Although in any process of political transition archives play a decisive role in the achievement of the values of truth, justice, and reparation, the Colombian case contains a series of particular characteristics which make it a truly exceptional case. In general, theoretical reflections of international scope which propose policies for human rights archives refer mainly to processes of political transition from a totalitarian regime to a democracy. Consequently, only a proportion of these reflections become inputs for the Colombian case, which constitutes a unique "model" in the international sphere, given that the armed conflict has arisen in a political context characterised by the consolidation of free elections and, therefore, also consecutive democratic governments. Or, to put it another way, the policies on human rights 
archives formulated in Europe and North America are reflected in the creation of a model which has become a "classic" one, based on the most recent experiences, and which has overwhelmingly taken shape in the more or less orderly transition from a totalitarian regime to a democracy (Latin America, especially the southern cone, southern Europe, and all the eastern European countries, among others). And in this general transitional model, it becomes difficult to adapt the peculiar Colombian situation that requires other referential elements, insofar as the peace process and its laws and resulting institutions constitute, in themselves, a specific "model".

Likewise, the Colombian experience has led to a great deal of support through international cooperation in the form of continued support from the United Nations through the Post-Conflict Multi-Donor Fund, the Inter-American Court of Human Rights, and the activism of countless civil organizations. The diversity of victimising events, the exceptional number of people affected, and the complexity of the different groups involved in the conflict has meant that the archives lie at the centre of the State's obligations to satisfy the rights of victims. There is, therefore, a great variety of archives which can contribute to providing evidence in this process, notably the archives of public institutions, social organizations, communities, and individuals who have kept documents relating to different forms of victimisation.

Our analysis will focus - in summarised form - firstly on consolidated institutions which produce and/or hold documents necessary for fully exercising the principles of truth, justice, and reparation. Secondly, we shall centre on the most emblematic institutions arising from the development of the Integral System of Truth, Justice, Reparation and Non-Repetition (SIVJRNR) and whose action is based unavoidably on the use of a wide typology of documents. These are not "archival" institutions in the traditional sense of the word; however, their capacity to exercise justice and make reparations is directly proportional to their ability to obtain documented information, analyse it, protect it, and use it in the first instance as evidence in trials.

Amongst the institutions in operation before the signing of the country's Peace Agreement (2016), we should highlight the National Archives, the governing body on archival policy in Colombia. As we have seen when analysing the legal framework, this has produced agreements aimed at identifying and protecting archives relating to human rights (HR) and international humanitarian law (IHL) and has structured part of its policies jointly with the CNMH. At another level, there are numerous high-ranking state and legal bodies which also produce enormous volumes of documents which are essential to exercise citizens' rights and prevent impunity. ${ }^{12}$ These institutions have formulated modern systems of document management as effective support for their function.

The Human Rights Archives under the CNMH provides a significant amount of quantitative information on archives in the public and private 
sectors, which clearly indicates the wide range of organizations involved at all levels. The Executive Branch identifies 73 archive sources on subjects relating to serious human rights violations, a figure which increases to 1,566 if we include all its branches. At the departmental level, there are 823 bodies producing archive material and 19,441 at the municipal level. As regards court archives, there are 2,712 bodies with 68 different branches, and the authorities on ethnic groups, registered by the Ministry of the Interior, record 4,289 indigenous and 2,044 Afro-Colombian bodies. With regard to the private sector, the archives of non-profit making organizations, for-profit legal bodies, and material held by individuals and families must all be considered. This sector contributes significant figures: 2,709 victims' organizations, 388 human rights organizations, 22 universities, 87 media, and 10,205 health care institutions. In short, 16,512 sources have been identified globally, of which an estimated 3,000 are archives with relevant information (Centro Nacional de Memoria Histórica, 2017, pp. 135-137).

An organization of great interest which has resolved the issue of the fit between archival bodies and other related services is National Centre for the Historical Memory. Created under Law 1448/2011 (Article 146) as a public institution with legal status, its own assets, and administrative and financial autonomy, its principal objectives concentrate on recovering all documents and oral testimonies of human rights violations and reflected in the creation of the Human Rights Archives Directorate. In turn, it is also responsible for creating a Museum of Memory, running the Human Rights and Historical Memory programme, and designing and implementing action in favour of historical memory. In addition, Decree 4800/2011 laid down the components of the Human Rights and Historical Memory Programme, focused on promoting research for the reconstruction of the country's historical memory, organising education programmes, implementing a special register of historical memory archives in conjunction with the National Archives Agency, and preparing a protocol for archival policy on human rights and international humanitarian law.

To achieve these objectives and comply with the legal mandate, in 2018, the CNMH created an organisational structure made up of five directorates: the Construction of Historical Memory, the Museum of Memory, the Human Rights and Historical Memory Archive, the Truth Agreements, and the Administrative and Financial Directorate (Centro Nacional de Memoria Histórica, 2014, pp. 22-24). Its strength lies in the fact that, far from creating fragmented bodies, the CNMH integrates the archives within the framework of its human rights and historical memory policies. The most relevant milestones in the field of archiving are the publication of pioneering public policy on human rights archives and a protocol for document management; the formulation of a series of educational tools; ${ }^{13}$ the creation of a virtual archive; and the appointment of an International Advisory Committee (IAC) as a permanent collegiate body whose main mission is to 
provide strategic and technical advice on missionary issues and to position the Colombian experience in dealing with the past and building peace. ${ }^{14}$

As we have already pointed out in the section on the legal framework, there are numerous organizations which focus on reparation for those affected by a multiplicity of acts of victimisation and which require robust document and information management models to advance efficiently and safely in their work. This would be the case of the Land Restitution Unit which devised a Document Management Programme through resolution 00951/2016, in line with the principles of the AGN, that includes a policy document; an Institutional Archives Programme, PINAR; an Integrated Conservation System, SIC; and a wide range of archival instruments (classification table, inventory, document retention Tables, and an index of classified and reserved information). Also noteworthy is the Unit for the Attention and Comprehensive Reparation of Victims, which attends to the needs of more than eight million registered victims - a substantial proportion due to forced displacement. It has a single register of victims and, under resolution 2043/2012, created a documentation management group to support this enormous task of information and document gathering. ${ }^{15}$

To conclude the analysis of this first group of archives, operating before the Peace Agreement was signed, we must necessarily refer to the military forces, police, and intelligence and counter-intelligence bodies. Currently (2020), the intelligence community is made up of the Administration Department: the National Intelligence Directorate or DNI, which has replaced the defunct Administrative Department of Security, or DAS, the Information and Financial Analysis Unit, or UIAF, the Police Intelligence Directorate, and 16 dependencies of the Military Forces (Ramírez Mourraille et al., 2017, p. 11). Although the DAS was disbanded by President Juan Manuel Santos through Decree 4057/2011 after the scandals arising from verification of illegal phone-tapping of opposition leaders, as well as the collusion of some of its top leaders with paramilitary groups and drug traffickers, the archival fonds amassed during the 51 years of its operation (July 1960 to October 2011) are extremely relevant.

For the conviction of 21 high ranking officials and DAS personnel for illegal espionage from 2003 to 2008 against 300 citizens catalogued as a threat to national security (Ramírez Mourraille et al., 2017, pp. 34-35), ${ }^{16}$ the prosecutor's office seized exactly 103 "ring binder folders" containing 51,000 pages on this espionage from the archive of DAS's Sub-directorate of Analysis.

The seriousness of this scandal, the repeated exhortations of the UN High Commissioner for Human Rights from the year 2000, as to the need to review intelligence files for the purpose of correcting and deleting incorrect information and verifying the difficulty of democratic control over this type of files, led to the creation of an "Advisory Commission for Data Filtering and Intelligence Files" under the Intelligence and Counter-Intelligence Law of 2013. 
For their part, the institutions created under the Comprehensive System of Truth, Justice, Reparation and Non-Repetition (SIVJRNR, Sistema Integral de Verdad, Justicia, Reparación y No Repetición) arising from the Peace Agreement were also involved in the creation of the Special Jurisdiction for Peace, or JEP; the Commission for the Clarification of the Truth, or CEV; and the Special Unit for the Search of Missing Persons, or UBPD (Spanish acronyms). The CEV and the UBPD are extrajudicial bodies (they do not attribute responsibility or seek to prosecute crimes) and the documents and information they produce or collect cannot be used as evidence in legal proceedings.

The Special Jurisdiction for Peace, or JEP, was created by Act 1957/2019 on Administration of Justice and has a limited mandate (in principle, 15 years, remaining in force until 2033) and its main mission is to provide justice by clarifying and establishing individual criminal liability for the most serious and most representative crimes committed during the Colombian armed conflict and determining the legal position of all those who appear before the JEP.

Its task, therefore, is focused on investigating, judging, and sanctioning in order to respect the rights of victims to the truth, justice, reparation, and guarantees of non-repetition. Consequently, the collection, organization, use of, and access to, documents become a central element in its action. Due to its powers and objectives, the JEP is comparable to an International Criminal Court (such as those created for Rwanda or for the former Yugoslavia in The Hague, among others), and functions as a transitional body of justice.

In this sense, it takes the shape of a Peace Tribunal with its different sections, courtrooms, and with an extremely complex organization chart. The Investigation and Prosecution Unit (IUA, Unidad de Investigación y Acusación) plays a key role, along with an Information Analysis Group (GRAI), which answers directly to the JEP presidency. ${ }^{17}$ The organization has an unequivocal desire for transparency, which is reflected in its website publication of the text of proceedings and judgments within 24 hours of their promulgation, and it also performs a function of disseminating the jurisprudence from court rulings, which could be relevant to other court bodies. Finally, it maintains a consistent policy model and document management system based on best practice and national and international conventions and regulations.

Another institution resulting from the SIVJRNR is the Commission for the Clarification of Truth, Coexistence and Non-Repetition (CEV). Created by Decree 588/2017, it is an autonomous and independent body of national order and constitutional rank, with legal status and administrative, budgetary, and technical autonomy. This is an extrajudicial body, composed of 11 commissioners chosen for their professional competence, open to the participation of victims, and with a three-year mandate. Its main objective is to contribute to the recognition of the victims and the clarification of 
the events that have occurred, with the aim of promoting coexistence and becoming an organization that imparts the values of peace and reconciliation. Aware of the value of the heritage archives that will be produced and collected by the CEV, the decree of creation places special emphasis on the urgent need for adequately organising the information collected and guaranteeing the preservation of its document legacy for the future, after the closure of the CEV (Ibáñez Najar, 2017). Special mention is also made of prioritising public access to the information in its archive. ${ }^{18}$

The Search Unit for Missing Persons (UBPD) is a state body of a humanitarian and extrajudicial nature whose objective is to direct, coordinate, and contribute to the search, firstly, for persons reported missing as a result of the armed conflict and who are still alive, and secondly, in the case of death, wherever possible, the recovery, identification, and decent release of the bodies. The UBPD is responsible for disappearances that occurred before the 1st of December 2016 (date of entry into force of the Peace Agreements), in the following circumstances: forced disappearance, kidnapping, illegal recruitment, as well as those occurring during the hostilities between regular combatants (members of the armed forces) and irregular combatants (members of armed groups operating outside the law). It has a 20 -year mandate to search for missing persons in order to uphold the rights to the truth and to reparation. In the different phases of this search, mention should be made of an initial stage of collecting, organising, and analysing information. By 2019 , this body had collected information on nearly 1,000 cases, out of an estimated total of nearly 100,000 missing persons.

\section{The challenges}

The leading role of the archives in overcoming the armed conflict and in achieving a stable and lasting peace is a clearly verifiable fact, especially given the key role attributed to them by the most recent Colombian legislation and the assumption by the majority of state institutions involved in the resolution of the conflict of the need for an efficient system of document and archive management. Together with this positive aspect - of major importance - there are still some challenges to be resolved which can be summarised in two main areas: access to archives and the preservation of the documentary legacy of the conflict.

In spite of clear moves forward in a culture of transparency which has permeated the majority of Colombian institutions, there are still some sectors holding key information subjected to restrictions and opacity. Probably the most obvious case is the difficulty of access to the archives of the so-called intelligence community - a problem not only attributable to Colombia endorsed by a notable allergy to the scrutiny of their actions by democratic bodies. The importance of a judicious opening of these archives is justified by the sensitive nature of the information held, although a detailed analysis of relevant legislation provides some clarification in a sector where general 


\section{Ramon Alberch i Fugueras}

limitations are imposed and information "overclassified". This abusive limitation, alluding to general "reasons of state" as the basis for refusal, is compounded by serious difficulty in exercising democratic control over the document and information management of this type of service. In the Colombian context, and following the arguments of a group of renowned jurists from the organization, Dejusticia, the laws applicable to the Intelligence Community are the following:

- Law 1581/2012. Statutory Law on Personal Data

- Law 1621/2013. Intelligence and Counter-Intelligence Act

- Law 1721/2014. Law on Transparency and Access to Public Information

- Law 1755/2015. Statutory Law on the Right of Petition.

According to the authors cited, the challenge which arises from this multiplicity of laws is that "three of the four laws produce a legal contradiction in terms of access to archives and that, in practice, this contradiction has been resolved by the intelligence and counter-intelligence community in favour of a restrictive interpretation of access to archives" (Ramírez Mourraille et al., 2017, p. 47). Specifically, the law on intelligence and counter-intelligence considers that the nature of the functions carried out by these bodies (Article 33), their documents, and information are reserved, so that the maximum period of 30 years can be applied to them. Experts question whether this criterion can be applied in cases of human rights violations, and after a detailed and rigorous analysis of the laws (Ramírez Mourraille et al., 2017, pp. 77-90), they argue that it is unconstitutional to maintain a complete reservation across the board on intelligence and counter-intelligence documents, from which only the JEP is totally exempted and the CEV and the UBPD partially exempted.

Another element which needs a rapid response at institutional level is the preservation of this extraordinary legacy of documents currently being produced by the group of institutions that we have characterised throughout this article. And this preservation faces two challenges which must be tackled in parallel: in the first place, the protection of the archives in the face of any hypothetical action of abandonment or destruction. Secondly, the need to preserve documents which, to a great extent, are being produced electronically and whose sustainability requires costly investment. Experts in digital preservation and international projects on the subject (InterPares, Erpanet, Life) emphasise the major costs involved in maintaining authenticity and quality of electronic documents, for the purposes of evidence, in view of constant technological obsolescence, format conversion, and the periodical migrations that this material suffers. The economic sustainability of information stored on digital media is a key element, as is the creation of secure and reliable repositories for the long-term preservation of authentic, complete, reliable, and usable electronic documents. 
A reasonable possibility would be for the institutions that produce archives during the course of the peace process to join forces to create a shared repository, particularly the National Archives, which already has a National Digital Archive (DNA), the CNMH, the JEP, and the CEV. In parallel, and as a measure of protection for the future, to undertake sequential and cumulative action consisting first of declaring these heritage archives as an Asset of Cultural Interest, to then pass on to the relevant procedures for their entry in the Programme Register of the "Memory of the World". Both actions, beyond the "physical" fate of the Archive, would give it considerable security and protection.

Other aspects which deserve further discussion would relate to the state of organization of the archives - a substantial proportion lacking classification tables and with a limited use of description and inventory standards as well as the lack of adequate digitization protocols which produce massive digital copying processes without adequate information retrieval support (OCR uses, metadata models, etc.).

It should be reiterated that these are archives produced for the resolution of a conflict and, consequently, must adhere to the principles of truth, justice, and reparation in the short and medium term. Nevertheless, we must not forget that with the passage of time, their value will increase, as they become essential instruments in the processes of memory recovery, historical research, and public education in order to guarantee the non-repetition of such a conflict. ${ }^{19}$

\section{Notes}

1 Among the large number of publications on the "armed conflict", we would like to highlight the key research work and dissemination by the National Centre for the Historical Memory through the publication of nearly 200 studies between 2013 and 2018, under the direction of Gonzalo Sánchez.

2 The ELN was founded in 1962; the FARC in 1965; the EPL in 1967; and later M-19 appeared as a breakaway group from the FARC.

3 Of the 10,440 victims, $60 \%$ were military and the remainder civilians. These figures put Colombia in second place in the world in terms of the number of victims of landmines and explosive remnants of war, or ERW, i.e. abandoned or used munitions that had not exploded, such as grenades, mortars, and bullets.

4 According to the UN Secretary General (2004), transitional justice is "the full range of processes and mechanisms associated with a society's attempts to come to terms with a past of large-scale abuse in order to hold those responsible accountable for their actions, to serve justice and achieve reconciliation".

5 A tighter international context - especially monitoring by the International Criminal Court - prevented the granting of a broader amnesty, such as the one granted in 1990 in the case of the M-19 guerrilla group.

6 Some authors use the concept of infoxication to refer to the multiplicity of laws, decrees, and agreements, which have been drawn up in recent years from different viewpoints and in the interests of exercising those powers. This legislation constitutes a veritable legal labyrinth for public bodies and associations. 


\section{Ramon Alberch i Fugueras}

7 In particular, External Circular 003 (29 May 2012) on the "Archive census and document inventory of attention to victims of the armed conflict in Colombia"; External circular 004 (29 May 2012) on the "Responsibility of the National Archives and the National Archives System on the question of human rights; the Historical Memory Archives on the implementation of Law 1448 of 2011, the Law on Victims" and finally, Agreement 004 (21 April 2015) which regulates "the complete administration, control, conservation, possession, custody and assurance of public documents relating to human rights and international humanitarian law, which are held in the archives of state institutions".

8 This group was abolished by Resolution 102 of the 22nd of February 2019, by the management of the AGN, the National Archives. This has been functioning since November 2012. The resolution cites as reasons for its suppression of the fact that it had already met the objectives set for its creation, in addition to existing budgetary difficulties.

9 Decree 4803/2011, which lays down the structure of National Centre for the Historical Memory (Article 12); Decree 2244/2011 adding some functions to the CNM; and Decree 4158/2011, determining the assignment of the CNM. It should also be noted that Decree 1081/2015 stipulates that human rights archives contain documents which refer to human rights violations in a broad sense and breaches of international humanitarian law. They also emphasise that human rights archives should be the object of the measures of preservation, protection, and access defined within the international framework of human rights, jurisprudence, domestic legislation, and, in particular, the final paragraph of Article 21 of Law 1712 of 2014.

10 In particular, agreements 1746/2003, 2589/2004, and 8707/2011.

11 To consult the final agreement signed between the National Government and the FARC-EP guerrillas (310 pages), see a summary document on the six major agreements adopted, prepared by the Office of the High Commissioner for Peace (16 pages).

12 As a guide, we should mention the Constitutional Court, the Supreme Court of Justice, the Upper Council of the Judiciary, the Office of the Public Prosecutor, the Ombudsman, the Office of the Attorney General, and the Office of the Comptroller of the Republic.

13 Política pública de archivos de derechos humanos, memoria histórica y conflicto armado, Bogotá 2017, and jointly with the AGN, the Protocolo de gestión documental de los archivos referidos a las graves y manifiestas violaciones a los derechos humanos, e infracciones al derecho internacional humanitario, ocurridas con ocasión del conflicto armado interno, Bogotá, 2017. In terms of educational work, we should highlight the Caja de herramientas para gestores de archivos de derechos humanos, DIH y memoria histórica. Bogotá, CNMH, 2015.

14 The IAC operated regularly from January 2015 to August 2018 and was composed of five international experts on past events, covering archives relating to human rights; museums and places of remembrance; research for historical clarification; and the processes of reconstruction of the historical memory.

15 A final example would be the National Observatory of Memory and Armed Conflict which has a methodological guide (Bogotá, January 2016) explaining how to collect, store, and analyse information; collection instruments; the identification of sources of information; the management of these sources; and data collection. It also provides guidelines for handling: integration, classification and coding, review and validation, data repositories, analysis and interpretation, dissemination and archiving. The information and databases produced have been periodically transferred to the $\mathrm{DH}$ Archives Directorate of the CNMH. 
16 In 2009, the prestigious magazine Semana denounced the illegal surveillance of judges, members of international human rights bodies, and also of the UN Special Rapporteur on indigenous peoples. The documents seized by the Attorney General's Office for the court case reflected the wealth of information that can be accumulated by intelligence agencies; in this case, interception of telephones and Internet lines, illegal surveillance, threats, smear campaigns, theft of information, and other actions aimed at creating a climate of intimidation and insecurity.

17 We emphasise the importance of the JEP organization chart, insofar as it visualises the consideration given to bodies such as the Court Registry, the Executive Secretariat, a Special Peace Tribunal with 20 judges, chambers of justice with three chambers and four sections, and specialised services such as the UIA, the GRAI, and the Department of Document Management, which centres on the documents and information that provide key evidence and testimony.

18 The authors of this decree emphasise the desire to make this legacy a lasting one, as they are aware of other experiences where documents produced and collected by the Truth Commissions have been left piled up in attics or offices after they were no longer required.

19 Due to its link with the subject of archives, without this being a central theme in this chapter, we would like to mention the profound debate which has arisen between jurists, academics, historians, archivists, and human rights defenders regarding both the duty and right to remember, with reasoned arguments referring, for example, to individual/collective truth and procedural/historical truth.

\section{Bibliography}

Archivo General De La Nación, Centro Nacional De Memoria Histórica. 2017, Protocolo de gestión documental de los archivos referidos a las graves y manifiestas violaciones a los derechos humanos, e infracciones al derecho internacional humanitario, ocurridas con ocasión del conflicto armado interno. Bogotá: AGN \& CNMH.

Centro Nacional de Memoria Histórica. 2013, ¡Basta yaj. Colombia: memorias de guerra y dignidad. Informe general grupo de memoria histórica. Colombia: Imprenta Nacional.

-2014, Memoria histórica en el ámbito territorial: orientaciones para autoridades territoriales. Bogotá: CNMH, pp. 22-24.

- 2017, Política pública de archivos de derechos humanos, memoria histórica $y$ conflicto armado. Bogotá: CNMH.

Centro Nacional de Memoria Histórica-Fundación Prolongar. 2017, La guerra escondida: Minas antipersonales y remanentes explosivos en Colombia. Bogotá: $\mathrm{CNMH}$.

Giraldo, Marta, and Toro, Luis, eds. 2018, Tramitar el pasado: Archivos de derechos humanos y museología viva. Medellín: Editorial Universidad Antioquia.

Ibáñez Najar, Jorge Enrique. 2017, Justicia Transicional y Comisiones de la Verdad, 2nd extended edition. Bogotá, Otzenhausen and Madrid: Biblioteca Derechos Humanos-Berg Institute.

Meto, Jorge Orlando. 2016, "Resumen del acuerdo de paz," Revista de Economía Institucional, vol. 18, no, 35, July-December.

Pécaut, Daniel. 2003, Violencia y política en Colombia: Elementos de reflexión. Medellín: Hombre Nuevo y Universidad del Valle. 


\section{Ramon Alberch i Fugueras}

Ramírez Mourraille, A. M., Ángel Arango, M. P., Albarracín CABALLERO, M., Uprimny YEPES, R., and Newman PONT, V. 2017, Acceso a los archivos de inteligencia y contrainteligencia en el marco del posacuerdo. Bogotá: DeJusticia.

Reyes, Alejandro. 2008, Guerreros y campesinos: El despojo de la tierra en Colombia. Bogotá: Grupo Editorial Norma.

Rodríguez, Jorge. 2017, Derecho a la Verdad y Derecho Internacional en relación con graves violaciones de los Derechos Humanos. Madrid: Biblioteca Derechos Humanos-Berg Institute.

Sánchez, Gonzalo, and Peñaranda, Ricardo, compilers. 2007, Pasado y presente de la violencia en Colombia. Bogotá: La carreta Editorial.

Tate, Winifred. 2007, Counting the Dead: The Culture and Politics of Human Rights Activism in Colombia. Berkeley: University of California Press.

\section{Web sources}

Archivo General de la Nación. Available at www.archivogeneral.gov.co.

Centro Nacional de Memoria Histórica. Available at www.centrodememoriahistor ica.gov.co y www.archivosdelosddhh.gov.co.

Comisión de Esclarecimiento de la Verdad. Available at https://comisiondelaverdad. co.

Dejusticia. Available at www.dejusticia.org.

Jurisdicción Especial para la Paz. Available at www.jep.gov.co.

Movimiento Nacional de Víctimas de Crímenes de Estado-MOVICE. Available at www.movimientodevictimas.org.

Rutas del Conflicto. Available at https://rutasdelconflicto.com.

Unidad Especial de Búsqueda de Personas Desaparecidas. Available at www.ubpd busquedadedesaparecidos.co.

Unidad de Restitución de Tierras. Available at www.restituciondetierras.gov.co.

Unidad para la Atención y Reparación de Víctimas. Available at www.unidadvicti mas.gov.co.

Verdad Abierta. Available at www.VerdadAbierta.com. 